\title{
平面性に基づいた測定点群の 階層的な領域分割による稜線抽出法
}

\author{
金野哲士 今野晃市 千葉則茂 \\ 岩手大学
}

\section{Ridge Lines Extraction by Hierarchical Planer Segmentation of Measured Point Clouds}

\author{
Tetsuji KONNO Kouichi KONNO Norishige CHIBA \\ Iwate University
}

E-mail: \{kontetsu, konno, nchiba\}@cis.iwate-u.ac.jp

アブストラクト

\begin{abstract}
レンジセンサを使用することで，建造物の幾何情報が点群として得られる．建造物全体の幾何情報を得るためには， 複数の点群を統合する位置合わせ処理が必要である.著者らは，これまで特徵線の一致を利用した位置合わせ手法を提 案してきた。しかし, 従来手法では, 位置合わせ処理に有効な特徽線を安定的に抽出するために, 厳しい測定条件が必 要であった。また, 有効な特徵線数が少ないため, 制限された位置から建造物を測定し, 得られた全ての点群を位置合 わせ処理する必要があった . 本論文では, 従来必要であった測定条件を緩和するために，建造物の稜線を表す特徽線の 抽出法を提案する. 本手法は, 従来手法で抽出した特徵線を用いて, 測定点群を階層的に領域分割する. 弚して, 隣接 する二つの領域の境界線として線分を生成することで, 稜線を表す特徵線を抽出する. 実験では, 測定して得られた点 群から稜線を抽出し位置合わせ処理を行い, 従来手法との比較を行った . 兴の結果, 本手法の有効性か確認された .
\end{abstract}

\begin{abstract}
Registration method unifies some point clouds measured by range sensor in order to get geometric information of whole building. In our previous method we use feature-line matching approach to get geometric information of a building but the result is not good enough because of the limited number of feature lines. In this paper, we extract ridge line to increase the number of feature lines. First, we applied the hierarchical crusting method which based on flatness of building to measured point clouds, then made a boundary line of adjacent two regions as a ridge line. As a result, our extended method has improved the restoring building and the strong constraint measurement conditions, compared to previous method.
\end{abstract}

キーワード：位置合わせ，特徵線，稜線，領域分割，平面性

Keywords : Registration, Feature Lines, Ridge Lines, Clustering, Flatness

\section{1 はじめに}

近年 ,レンジセンサから得られた建造物の幾何情 報からポリゴンモデルを作成し，光のポリゴンモデ ルで構成された都市空間をウォークスルーするよ うな VR コンテンツが増加している.レンジセン サを使用することで，建造物の幾何学的な情報が点 群として得られる . 得られた点群に基づいてモデ リングを行うことにより，建造物との幾何学的な整 合性を保持したポリゴンモデルが生成可能となる． 以下では, 一つの方向から測定して得られた点群を
単位点群と呼ぶ．図 1 に単位点群の例を示す. 図 1 に示すような一つの単位点群だけでは, 建造物全体 をモデリングするための幾何情報が不足している . 弚のため, 建造物を複数の方向から測定し, 得られ た複数の単位点群を同一の空間に適切に配置する ことにより，不足した幾何情報を補うことが可能と なる．このような処理を効率化するものとして，複 数の単位点群を自動的に配置する位置合わせ手法 が挙げられる。

位置合わせ手法は, 主に点ベース $[1 \sim 6]$ と特徵 量ベース [7〜13] の手法に分類される . 点ベースの 代表的な手法として, Besl らの Iterative Closest 


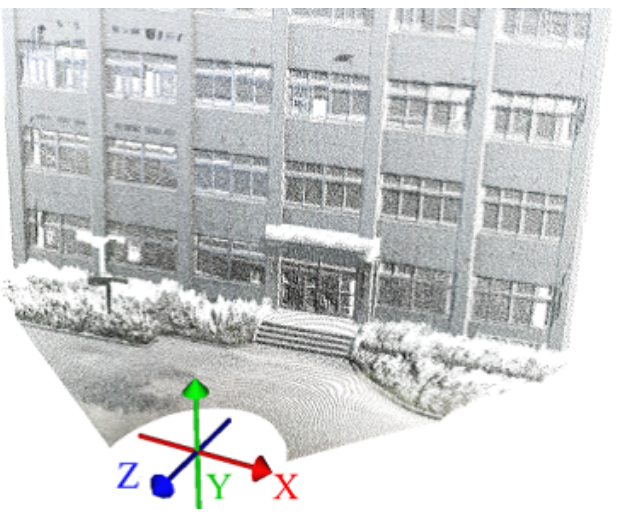

図 1 単位点群の例

Point(ICP) アルゴリズムを用いた位置合わせ手法 が挙げられる [1] . ICP アルゴリズムは , 二つの単 位点群に关れ属する点と点の距離を基に誤差 評価関数を定義し，弚の誤差評価値が最小となるよ うな幾何変換を求める手法である．また，Ikeuchi らは，PCクラスタを用いて複数の単位点群を同時 に位置合わせ処理する手法を提案し，膨大な点群を 高速で位置合わせ処理することが可能となった [5] .

一方，位置合わせ処理の計算時間を短縮する別の アプローチとして, 特徵量ベースの手法が挙げら れる.Akca らは，建造物に貼付したマーカーを特 徵点として単位点群から抽出し, 特徵点を誤差評 価基準とした位置合わせ手法を提案した $[9]$ ．また， Stamos らは, 単位点群を平面で領域分割すること で特徵線を抽出し, 兴の特徵線と平面を誤差評価基 準とした位置合わせ手法を提案した [10] . 本手法で は, Stamos らの手法と異なるプロセスで単位点群 を領域分割し，稜線を抽出する．

著者らも，これまで，近代的な建造物を対象とし て，特徵線の一致を利用した点群位置合わせ手法を 提案してきた [13]. 文献 [13] の手法では，はじめ に，デプスエッジを基に線分を生成することによ り, 単位点群から特徵線を抽出した。产の結果，建 造物のシルエットを表すような特徵線が安定的に 抽出可能となった．次に，二つの単位点群から关れ 光れ抽出した特徵線を適切に配置するような幾何 変換を算出し, 単位点群に適用することで位置合わ せ処理を行った . 文献 [13] の手法では，長い特徵 線が建造物の特徵を顕著に表していると仮定し，位 置合わせ処理に有効な特徵線として使用した．し かし，長い特徵線を安定的に抽出するために，厳し い測定条件を設ける必要があつた。また，有効な特 徵線数が少ないため，建造物全体の幾何情報を表す
点群を得るためには, 厳しい測定条件の下で複数の 方向から建造物を測定して単位点群を蓄積し，全て の単位点群を位置合わせ処理する必要があった .

本論文では, 文献 [13] で述べた測定条件を緩和 し，より安定的な位置合わせ処理を行うために，文 献 [13] の拡張手法を提案する. 本手法では, 点の 接平面を表す法線ベクトルが等しい点の集合がー つの平面領域を構成するものとして, 単位点群を階 層的に領域分割する. 光して, 隣接する二つの平面 領域の境界部分から稜線を算出する. 以上のよう に，建造物の平面性という着眼点を文献 [13] の手 法に加えることにより，従来の測定条件が緩和され る、また, 稜線を表す特徵線を抽出し, 位置合わせ 処理に有効な特徵線数が増加することにより, 位置 合わせ処理の安定性が向上する .

\section{2 関連研究}

\section{1 領域分割手法}

本手法では，建造物の平面性に基づいて単位点群 を領域分割し，隣接する二つの領域の境界線を稜線 として抽出する．このような稜線が抽出される位 置は, 領域分割の結果に依存する。よって, 実際の 建造物の稜線を表すような特徵線を求めるために は, 適切な領域分割結果が得られる必要がある.— 般的に, 単位点群の領域分割手法は, プリミティブ ベース [14〜16], エッジベース [17〜19] , リージョ ンベース $[20 \sim 22]$ の 3 種類に分類される .

プリミティブベースは, 平面や球といった単純 なモデルを単位点群にあてはめ, 谷のモデルと一 致するような点群を一つの領域として抽出する手 法である. Wang らは, Adaptive Scale Sample Consensus (ASSC) と呼ばれる評価アルゴリズム を提案し，測定誤差を含んだ単位点群を領域分割可 能とした [14] . プリミティブベースの手法では, 単 位点群に対して, モデルの適切な初期位置を求める 必要がある。

エッジベースは, 輝度画像のような, 測定時に得 られた 2 次元画像上でエッジ検出を行い，複数の エッジに囲まれる点群を一つの領域として抽出す る手法である . Zhang らは , 測定時に得られた輝 度画像と距離画像から 3 種類のエッジを検出した [18]. 乥して，3 種類のエッジを統合し，単位点群 の領域分割を行った . エッジベースの手法では , ノ 
イズ除去のために，平滑化のような前処理を伴った エッジ検出が必要である .

リージョンベースは, 領域分割の開始点として単 位点群上の一点を指定し，法線ベクトルや二点間の 距離といった局所的な幾何情報が等しい点をグルー プ化する手法である.リージョンベースの手法で は, 適切な開始点を指定できれば, 前処理を必要と せずに領域分割が容易にできる利点がある．本手 法も，このような利点を有用するため，リージョン ベースの手法に基づいて領域分割を行う．Stamos らは, 単位点群上の一点を一つの平面として定義 し，お互いに包含する平面同士をグループ化するこ とで領域分割を行った [10] 。しかし，Stamos の手 法では，領域分割の開始点を無作為に指定した場 合, 意図する領域分割結果が得られない可能性があ る.よって本手法では, 文献 [13] の特徵線抽出処 理で使用した点列を開始点の集合として，領域分割 を行う.

単位点群上の一点は, 3 次元空間上の座標値で表 されているため, 光の点がどのような面情報に基づ いて配置されているのか不明である．したがって， リージョンベースの手法では, 領域分割の適切な開 始点を指定することが容易ではない，本手法では， リージョンベースの問題点を解決するために, 文献 [13]の手法で抽出した特徽線を構成する点列を開始 点の集合とした領域分割を行う．

\section{2 従来手法}

本節では, 著者らが文献 [13] で提案した, 特徽缐 の一致を用いた点群位置合わせ手法の概要を述べ る.一般的に，近代的な建造物は直線的な特徵を多 数保持しており, 光の特徵を表すような特徵線が容 易に得られれば, 安定した位置合わせ処理を行うこ とができる、文献 [13]では，この点に着目して，デ プスエッジを用いた特徵線抽出を行った .ただし， デプスエッジは奥行き方向の差分を利用して抽出 するため, 弚の特徵か顕著に現れるように, 以下に 述べる建造物の測定条件を満足する必要があった．

- 建造物の特徵部分の近辺が, 奥行き方向で 大きく変化するようにレンジセンサを配置 する．

- 建造物上の特徵部分が, 二つの測定方向で障 害物に遮られず，点群として得られるように

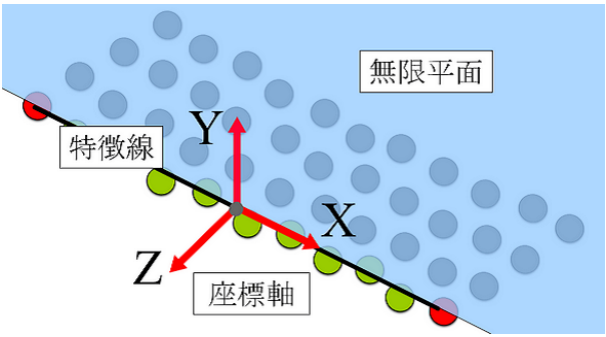

図 2 線分上の局所的な座標軸

レンジセンサを配置する .

測定条件に基づいて建造物を測定し, 得られた複 数の単位点群について位置合わせ処理を行う. 特 徵線の一致を用いた点群位置合わせ処理は, 特徵線 の抽出処理と特徵線のマッチング処理に分けられ る.特徵線の抽出処理では, はじめに，建造物の特 徵部分を表す点列を抽出するために, 隣接する二点 間で奥行き方向の差分が大きい点列をデプスエッ ジとして抽出する . 抽出した点列を直線的な特徵 量ごとに複数のセグメントに分割し, 各セグメント を線分で近似することで，特徵線を生成する．本論 文では, 単位点群から抽出した複数の特徽線を特徵 線群と呼心゙．

特徵線のマッチング処理では, RANSAC アルゴ リズム [23] に基づいた特徵線の組み合わせを行い， 二つの特徵線群間で一致した特徵線ペアが最大と なるような幾何変換を算出する．仮に, 二つの特徵 線の端点間距離が, $\varepsilon_{\text {distance }}$ よりも小さい場合, 二 つの特徵線は一致すると判断する.ただし, 単位点 群は測定誤差を含んでいるため, 建造物の幾何学的 な特徵を顕著に表した長い特徽線を用いて幾何変 換を算出する．また，前処理として，图 2 に示すよ うな局所的な座標軸を各特徽線上に設定し, マッチ ング処理に使用する . はじめに, 特徽線と近傍の点 群を包含するような無限平面が存在すると仮定し， 光の無限平面の単位法線ベクトルを近似的に算出 する. 光して, 無限平面の単位法線べクトルに基づ いて局所的な座標軸を設定する .

图 3(a) に示す正二十面体ポリゴンから単位点群 を擬似的に生成し,文献 [13]の手法て抽出した特徵 線群を图 3(b) に示す. 图 3(b) の青い太線が抽出し た特徽線であり, 灰色の領域は単位点群を表す，図 3(b) から分かるように, ポリゴンのシルエットを 表すような外側の特徽線が抽出されているが, 棱線 を表す内側の特徵線は全く抽出されていない．こ 

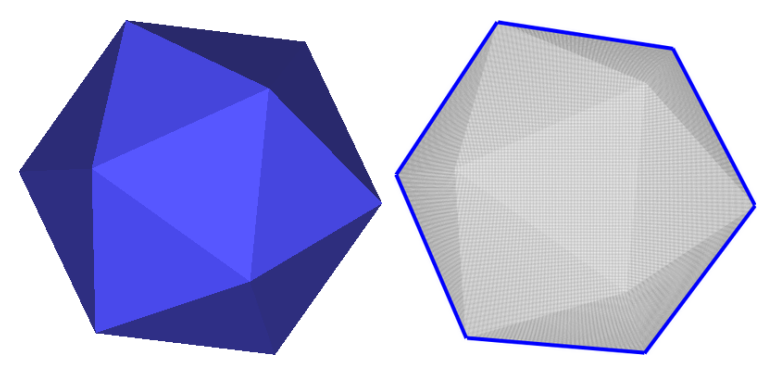

(a) ポリゴン (b) 特徵線群

れは, 奥行き方向の差分が大きい部分のみを, 特徵 線の抽出対象としたことが原因である. 本手法で は,文献 [13] で提案した手法を拡張し，稜線を表す 内側の特徵線を抽出する.

\section{3 拡張手法}

文献 [13] の手法では奥行き方向の差分に着目し て特徵線を抽出したが, 本手法では, 新たな特徵量 として建造物の平面性に着目する。一般的に，建造 物の表面形状は平面を多用しており，測定して得ら れた単位点群も，弚の平面に基づいて配置されてい る. 本手法では，建造物の表面形状を複数の平面で 領域分割するように, 単位点群を複数の平面領域 に分割する .このとき, 各平面領域に属する点群が 取り出される. 光して, 取り出した点群に文献 [13] の手法を適用し，特徵線を抽出する. 弚の結果，抽 出した特徵線は, 各平面領域のシルエットを表す特 徵線となる .このように, 平面領域に属する点群か ら特徵線を抽出することで，建造物の内側に存在す る特徵線を抽出する．また，隣接する二つの平面領 域において , 光のシルエットを表す特徵線が重なる 場合，二つの領域の交線として稜線を生成し，特徵 線を最適化する.

\section{1 領域分割}

リージョンベースの領域分割結果は, 開始点の局 所的な幾何情報に依存する.正しい領域分割結果 を得るためには,一つの平面領域に属する可能性が 高い一点を開始点とする必要がある．しかし， 2.1 節で述べたように，適切な開始点を指定することは 容易でない .このような問題点を解決するために，

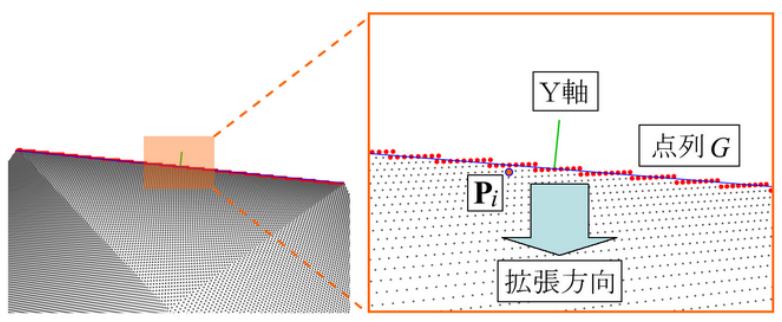

図 4 局所的な $\mathrm{Y}$ 軸に基づいた領域分割

本手法では特徵線を構成する点列を開始点とする . 文献 [13] では，隣接点との奥行き方向の差分が大 きい点列をデプスエッジとして抽出し, 特徵線を 生成した . 兴のため, 一つの平面領域に属する点群 が特徵線の片側に存在し, 特徵線を構成する点列 も，弚のような平面領域に属している可能性が高 い.また， 2.2 節で述べたように, 文献 [13] の手法 でも，特徵線の近傍にある点群を包含するような無 限平面を想定し，局所的な座標軸を設置した よよっ て本手法では, 特徵線を構成する点列が, 一つの平 面領域に属する可能性が高い開始点の集合である として，以下の手順で領域分割を行う。

1. 特徵線抽出

入力された単位点群に文献 [13] の手法を 適用し，特徽線を抽出する.ただし，2.2 節 で述べたように，建造物の幾何学的な特徵を 顕著に表すような, 長い特徽線を後述の処理 に使用する .

2. 単位点群の探索

特徵線を構成する点列を開始点として，一 つの平面領域に属する点群を探索する . 文 献 [13]の手法では, 特徵線と炎の近傍の点群 を包含するような無限平面が存在すると仮 定し, 近似的に求めた無限平面の法線べクト ルに基づいて , 特徵線上の局所的な $\mathrm{Y}$ 軸を 設定した . 兴のため, 特徽線上の局所的な $\mathrm{Y}$ 軸方向と, 無限平面に包含される点群の接平 面を表す単位法線ベクトルの方向が, ほぼ等 しい可能性が高い.よって, 本手法では, 特 徵線上の局所的な $\mathrm{Y}$ 軸と, 点の接平面を表 す単位法線ベクトルがなす角度に基づいて， 以下の手順で点群を探索する .

(a) 特徵線を構成する点列から，一つの平 面領域を構築する。仮に，この点列を $G$ とし, 点列 $G$ が属する平面領域を $A$ と 


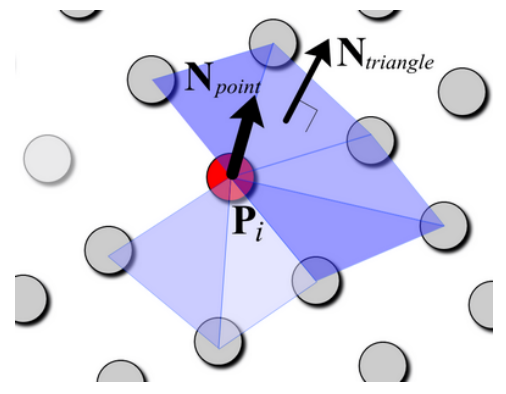

図 5 点の接平面を表す単位法線ベクトル

する.図 4 では, 図 3(b) に示した特徵 線から領域分割を行う場合の, 特徵線付 近の拡大図を示す . 図 4 において, 赤い 点列で表されたものを点列 $G$ とする .

(b) 図 4 の緑線で示すような特徽線上の 局所的な $\mathrm{Y}$ 軸と, 点列 $G$ に隣接する点 群 $\mathbf{P}_{i}$ の接平面を表す単位法線べク卜 ル $\mathbf{N}_{\text {point }}$ がなす角度 $\theta_{i}$ を求める.こ こで, 単位法線べクトル $\mathbf{N}_{\text {point }}$ は, 図 5 に示すように, 点 $\mathbf{P}_{i}$ の周囲 1 近傍 に隣接する点を用いて算出する . 点 $\mathbf{P}_{i}$ と，弚の周囲 1 近傍に隣接する 2 点で 構成される三角形面の法線ベクトルを $\mathbf{N}_{\text {triangle }}$ とすると， $\mathbf{N}_{\text {point }}$ は式 (1)で 表される .

$$
\mathbf{N}_{\text {point }}=\frac{1}{n} \sum_{i=0}^{n-1} \mathbf{N}_{\text {triangle }}^{i}
$$

ただし, $n$ は三角形面の総数とする . 仮 に角度 $\theta_{i}$ が閾値 $\sigma_{\min }$ から $\sigma_{\max }$ の範 囲内となる場合，隣接点 $\mathbf{P}_{i}$ を平面領域 $A$ に含める．ただし，閾値 $\sigma_{\min }, \sigma_{\max }$ は局所的な $\mathrm{Y}$ 軸との最小角度，および 最大角度とする . 閾値の調整は, 許容誤 差の設定と等価であることから，測定誤 差を含んだ単位点群を適切に領域分割 することができる .

(c) 平面領域 $A$ に新たに属した点群を点 列 $G$ として処理 (b) を繰り返し行い, 平面領域 $A$ を拡張していく.

処理 (a)〜 (c) を行った結果, 特徵線が境界 線の一つとなるような平面領域に属する点 群が得られる .

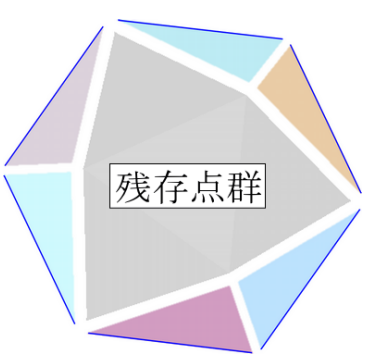

(a) 一回目

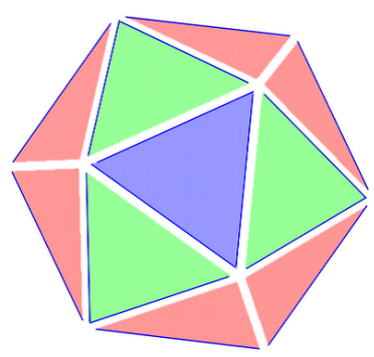

(b) 最終結果
図 6 領域分割の結果

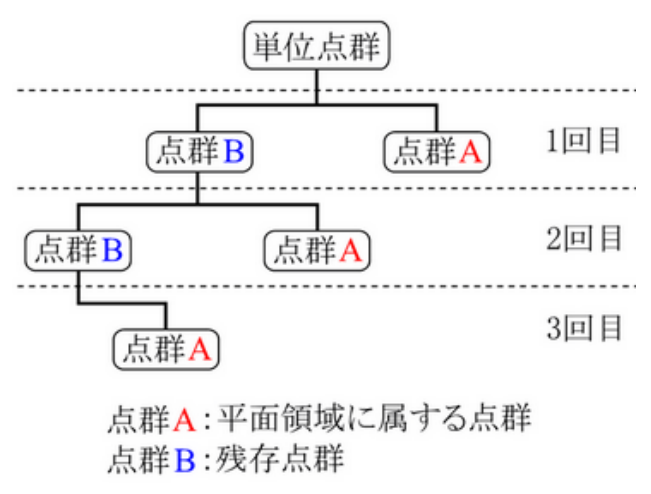

図 7 二分木で表されるデータ構造

図 3(b) に示した青色の特徵線を使用して，領域 分割を行った結果を図 6(a) に示す. 図 6(a)では， 各平面領域に属する点群を異なる色で表しており， 中央の灰色部分は領域に属さない残存点群を表す． 図 6(a)から分かるように,一回の領域分割では, 全 ての点群を領域分割することができない．弚のた め，領域分割されなかった残存点群に文献 [13] の 手法を適用し，新たな特徵線を抽出する. 乥して， 抽出した新たな特徽線を用いて処理 $(\mathrm{a})$ 〜 (c) を再 度適用し，領域分割を繰り返す.最終的な領域分割 結果を図 6(b) に示す. 最終的な領域分割回数は 3 回であったため, 図 6(b) では, 赤色の平面領域を 1 回目，緑色の平面領域を 2 回目，青色の平面領域を 3 回目に領域分割されたものとして表している.ま た，図 6(b) に示した最終的な領域分割後のデータ 構造は, 図 7 に示すような二分木で表される . 図 7 では, 一回目の領域分割によって, 単位点群は平面 領域に属する点群と平面領域に属さない残存点群 に分割され，二回目の領域分割結果も同樣となる . 以上のように, 残存点群に対する特徵線抽出と, 平 面領域に属する点群の探索を繰り返し行うことで, 単位点群が階層的に領域分割される。 


\section{2 稜線生成}

稜線のような対象物の内側に存在する特徵線を 得るために, 文献 [13] で提案した手法を平面領域 に属する点群に適用し，平面領域のシルエットを表 す特徵線を改めて抽出する．ただし， 3.1 節で述べ たように，建造物の幾何学的な特徵を顕著に表すも のとして，長い特徵線を棱線生成に使用する．隣接 する二つの平面領域の境界部分では, 抽出した特徵 線が重なる場合がある．2.2 節で述べたように, 文 献 [13] で提案したマッチング処理では特徵線の組 み合わせを用いて幾何変換を求めている.マッチ ング処理の計算コストを減少させるためには, 重複 している二つの特徽線を一つにまとめる必要があ る.よって本手法では, 重複した二つの特徽線を一 つの稜線に最適化する．次項では，重複した二つの 特徽線の探索方法を述べる.

\subsection{1 重複した特徵線の探索}

重複している二つの特徵線を探し出すために, 二 つの平面領域ごとに特徵線の一致判定を行う. 図 7 に示すように，領域分割された単位点群のデータ 構造は二分木で表される.本手法では，深さ優先 探索を用いて二つの平面領域を組み合わせ, 平面 領域のシルエットを表す特徽線の一致判定を行う. ただし, 単位点群は測定誤差を含んでいるため, 二 つの特徵線の端点が完全に一致する可能性は低い . よって, 文献 [13] で定義したように,二つの特徵線 の端点間距離が, $\varepsilon_{\text {distance }}$ よりも小さい場合, 二つ の特徵線が一致していると判定する .

重複した特徵線を発見した後に,二つの特徵線を 一つの稜線に最適化する. 説明のために , 隣接する 二つの平面領域 $A, B$ に含まれる点群を $G a, G b$ とする . はじめに, 稜線の方向べクトルを定めるた めに, 平面領域 $A, B$ の交線を表すような無限直線 を算出する . 次に, 点群 $G a, G b$ を用いて無限直線 上に稜線の端点を生成し，关の端点を連結した線分 を稜線とする．次項では，各処理を詳細に述べる．

\subsection{2 無限直線の算出}

本手法では, 隣接する二つの平面領域 $A, B$ を光 れ光れ包含するような, 二つの無限平面の交線を無 限直線として算出し稜線を生成する.二つの平面

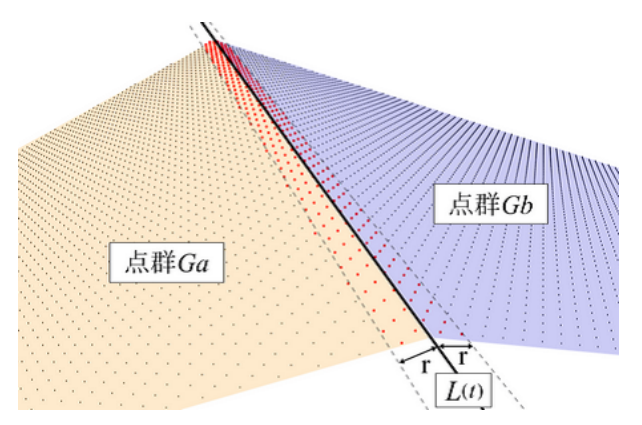

図 8 端点候補の絞込み

領域 $A, B$ の境界線となるような, 最適な無限直 線は, 無限平面の法線ベクトルの向きと原点の位置 に依存する・よって, 平面領域に属する点群を用い て，弚の無限平面を最適化する.

例えば, 平面領域 $A$ を包含するような無限平面 の単位法線ベクトル $\mathbf{N}_{a}$ と原点 $\mathbf{P}_{g}$ を算出する場 合を考える .このとき, 単位法線べクトル $\mathbf{N}_{a}$ は, 平面領域 $A$ に属する点群 $G a$ において, 各点の接 平面を表す単位法線ベクトル $\mathbf{N}_{i}$ の平均とする . ま た，無限平面の原点 $\mathbf{P}_{g}$ は点群 $G a$ の重心とする . 隣接する平面領域 $B$ に対しても同樣の最適化を行 い, 二つの無限平面の交線を求めることで, 棱線の 方向ベクトルを表す無限直線を算出する .

\subsection{3 無限直線の線分化}

3.2 .2 項では, 隣接する二つの平面領域 $A, B$ の 境界線として, 最適な無限直線を求めた、本節で は, この無限直線を線分化するために, 無限直線上 に二つの端点を定義する．光して，二つの端点を連 結した線分を稜線とする.本手法で求める稜線は, 隣接する二つの平面領域の境界線となるため, 二 つの平面領域 $A, B$ で共有する境界稜線となる必 要がある・よって, 境界稜線を求めるために, 点群 $G a, G b$ から棱線の端点となる可能性が高い二点を 検出する .

はじめに, 稜線の端点となる可能性が高い複数の 候補点を点群 $G a, G b$ から探索する. 本手法では 二つの平面領域の境界部分に稜線を生成するため, 棱線の端点となる可能性が高い二点は, 弚の境界 部分に生成した無限直線の近傍に存在すると考え られる.よって, 図 8 に示すように, 点群 $G a, G b$ に対して無限直線 $L(t)$ から距離 $r$ 内に存在する点 列を探索することで, 端点候補の絞込みを行う．た だし, 境界部分で重複している二本の特徵線におい 


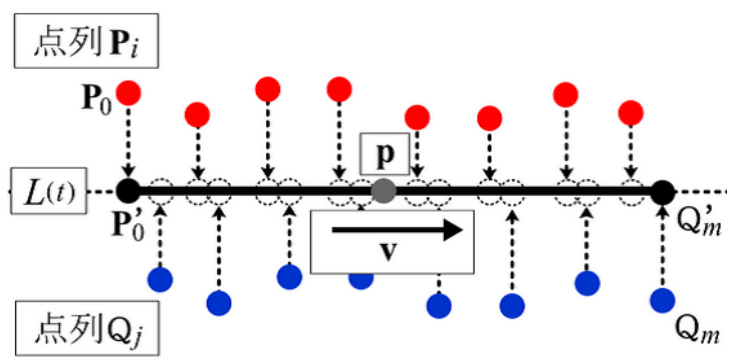

図 9 端点の検出

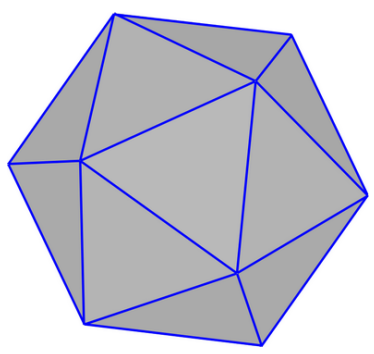

図 10 稜線抽出結果

て, 各特徵線を構成している点から無限直線 $L(t)$ までの最大距離を $r$ とする .

2.2 節で述べたように，文献 [13] では，建造物の 幾何学的な特徵を顕著に表した長い特徵線が , マッ チング処理に有効な特徵線であるとした．弚のた め，本手法では，算出した棱線をマッチング処理に 有効な特徵線とするために，稜線の長さが最大とな るように端点を検出する．図 9 に示すように，点群 $G a, G b$ から探索した点列 $\mathbf{P}_{i}, \mathbf{Q}_{j}$ を無限直線 $L(t)$ に射影し，無限直線上の位置を表わすパラメータ $t$ を算出する．ただし，無限直線 $L(t)$ の方向ベクト ルを $\mathbf{v}$ とし， $L(t)$ が通る一点を $\mathbf{p}$ とすると，パラ メータ $t$ は式 $(2)$ で表される .

$$
t=\frac{\left(\mathbf{P}_{i}-\mathbf{p}\right) \cdot \mathbf{v}}{|\mathbf{v}|^{2}}
$$

パラメータ $t$ が最大 , 最小となるような二つの射影 点を稜線の端点とする . 例えば，図 9 では，点 $\mathbf{P}_{0}$ と点 $\mathbf{Q}_{m}$ を無限直線 $L(t)$ に射影した二点 $\mathbf{P}_{0}^{\prime}, \mathbf{Q}_{m}^{\prime}$ が棱線の端点となる．図 6(b) に示した領域分割結 果を用いて，稜線を抽出した結果を図 10 に示す。 図 3(b) と比較すると，内側の稜線が抽出されてい るのが分かる .

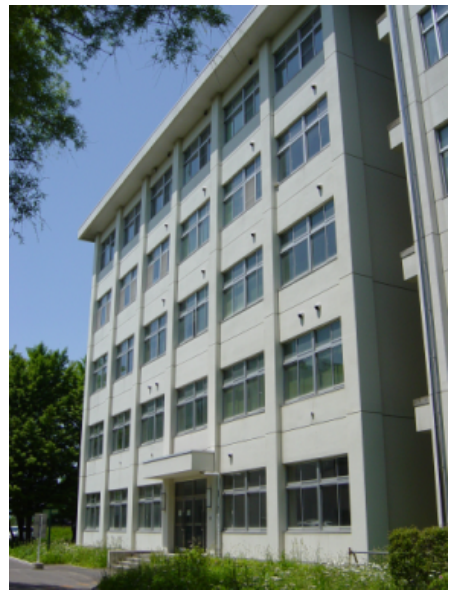

図 11 測定対象の建造物

\section{4 実験}

本章では，建造物を測定して得られた単位点群に 対して，本手法を適用した結果を示す．また，文献 [13] の実験結果に対する比較と検討を行い, 本手法 の有効性を示す . 文献 [13] の実験では, 图 11 に示 した建造物を測定し，位置合わせ処理を行った．し かし, 文献 [13] の手法では, 位置合わせ処理に有効 な特徵線を安定的に抽出するために, 厳しい測定条 件が必要であった．また，位置合わせ処理に有効な 特徵線数が少なかったため, 建造物全体の幾何情報 を表す点群を得るには，厳しい測定条件の下で，複 数の位置から建造物を測定し, 単位点群を蓄積する 必要があった . 図 12 では, 文献 [13] の手法を用い て抽出した, 位置合わせ処理に有効な特徵線群を示 す．ただし，文献 [13] の実験と同樣の条件の下で 有効な特徵線を選出した．図の青線は特徵線を表

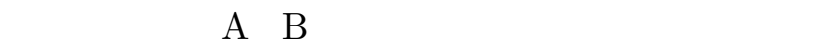
一致した特徵線を表す．また，黑い微小な点群は測 定して得られた単位点群を表す，一般的に，特徵線 を利用して二つの単位点群を位置合わせ処理する ためには, 少なくとも二組の特徵線が一致する幾何 変換を算出する必要がある.しかし, 図 12 に示し

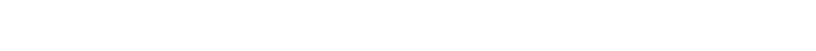
ず，正しい位置合わせ処理結果が得られなかった .

図 12 に示した特徵線群を用いて, 本論文で提案 した拡張手法を適用した結果を図 13 に示す.図 13 の赤い太線は後述のマッチング処理で一致した特 徵線である．本実験で設定した閾値は，文献 [13] の実験結果を参考にして， $\varepsilon_{\text {distance }}=0.1(m)$ とし た. 図 12 と比較すると, 図 13 では, 建造物の稜線 
を表す特徵線が抽出されているのが分かる . また , 図 14 は,図 13 に示した棱線抽出の基となる平面領 域を示す . 同一色の領域が一つの平面領域を示す . 隣接する平面領域の境界線として, 棱線が生成され ていることが分かる.本実験では，図 12 に示した ような，建造物のシルエットを表す特徵線が得ら れれば，棱線を表す特徵線の抽出が容易となった． よって，測定時には，建造物の内側で奥行き方向の 大きな差分が顕著に現れるような, 従来必要であつ た測定条件を緩和できる .

図 13 に示した特徵線群をマッチング処理した後 の点群を図 15(a) に示し, 特徵線を図 15(b) に示 す.図 15 では, 測定方向ごとに単位点群と特徵線 群を異なる色で表す.本実験では, 図 13(b) の特徵 線群に対して，はじめに図 13(c) の特徵線群をマッ チング処理した . 次に, 兴の統合した特徵線群に対 して, 図 13(a) の特徵線群をマッチング処理した . ただし，文献 [13] の実験と同樣の条件の下でマッ チング処理を行った . 表 1 に本実験のマッチング 処理の推移を示す. 表 1 では単位点群ごとに , 測定 方向, 点の数, マッチング処理に有効な特徵線数, 一致した特徵線のペア数および平均誤差值 $E$ を示 す. 平均誤差值 $E$ は，一致した特徵線のペアにお いて, 乥の端点間の距離の加算を平均したものであ る.表 1 の括弧内の数字は, 文献 [13] の手法を適 用したときの值である . 表 2 では, 各マッチング処 理に要した特徵線の組合せ数, 計算時間および消費 メモリ量を示す. 表 1 や表 2 から分かるように, 文 献 [13] の実験結果と比較すると, 組合せ数に応じた 計算時間や, 点の数に応じた消費メモリ量が同等で あるにもかかわらず, 有効な特徵線数や一致した特 徵線ペア数が増加している.また, 文献 [13] の実 験結果では, 一致した特徵線のペア数が少なく，光 の平均誤差値が $0.10 〜 0.21(\mathrm{~m})$ であった . しかし， 表 1 では, 一致した特徵線のペア数が増加したにも かかわらず, 平均誤差値が $0.01 〜 0.02(\mathrm{~m})$ となり， 文献 [13] の手法よりも厳密な位置合わせ処理を行 うことができた . 本実験では, 本論文で提案した拡 張手法を適用することにより, 文献 [13] の手法で 抽出できなかった稜線が新たに抽出された．光の 結果, 文献 [13] の手法では位置合わせ処理できな かった単位点群も位置合わせ処理が可能となり, 位 置合わせ処理の安定性か増加した .
表 1 マッチング処理の推移

\begin{tabular}{c|c|c|c|c|c}
\hline \hline 回数 & 方向 & 点 & 特徵線 & 合致数 & 誤差 $(\mathrm{m})$ \\
\hline- & 2 & 362112 & $27(9)$ & - & - \\
\hline 1 & 3 & 403803 & $21(3)$ & $8(1)$ & 0.02 \\
\hline 2 & 1 & 355221 & $18(6)$ & $4(1)$ & 0.01 \\
\hline \hline
\end{tabular}

表 2 計算時間とメモリ量

\begin{tabular}{c|c|c|c}
\hline \hline 回数 & 組数 & 時間 $(\mathrm{s})$ & 点群と特徵線群 $(\mathrm{MB})$ \\
\hline 1 & 114 & 2.52 & 114.29 \\
\hline 2 & 50 & 0.42 & 178.32 \\
\hline \hline
\end{tabular}

\section{5 まとめ}

本論文では, 文献 [13] で定義した建造物の測定 条件を緩和するために，建造物の稜線を表す特徵線 の抽出手法を提案した .はじめに, 建造物の平面性 に基づいて単位点群を階層的に領域分割し, 平面領 域に属する点群を抽出した．次に，平面領域に属す る点群に文献 [13] の手法を適用することで, 平面 領域のシルエットを表す特徵線を抽出した . 隣接 する二つの平面領域で特徵線が重複した場合, 光の 二つの平面領域の交線として稜線を生成した。棱 線を表す特徵線が抽出可能となったことで, 従来必 要であった測定条件が緩和され, 位置合わせ処理 の安定性か増加した . 今後の課題として , オクルー ジョンの発生によって断片化した特徵線を最適化 する手法を開発する必要がある.

\section{謝辞}

本研究の一部は, 平成 18 年度 JST サテライト岩 手実用化可能性試験, および科学研究費補助金 (基 盤研究 (B)16300021) の支援による .

\section{参考文献}

[1] P. Besl and N. McKay, "A Method for Registration of 3-D Shapes, "IEEE Trans. Pattern Anal. \& Mach. Intell. Vol.14. No.2. pp.239-256, 1992.

[2] Y. Chen and G. Medioni, "Object Modeling by Registration of Multiple Range Images, "Image and Vision Computing, Vol.10, issue 3, pp.145-155, 1992.

[3] Turk G. and M. Levoy, "Zippered Polygon Meshes from Range Images, "SIGGRAPH'94, pp.311-318, 1994.

[4] B. Curless et al. "From Range Scans to 3D Models, "Appears in Computer Graphics Vol.33. No.4, 1999. 
[5] K. Ikeuchi, A. Nakazawa, K. Hasegawa and T. Ohishi, "The Great Buddha Project: Modeling Cultural Heritage for VR Systems through Observation, "IEEE ISMAR03 pp.7-17, Tokyo, Japan, Nov. 2003.

[6] N. J. Mitra, N. Gelfand, H. Pottmann and L. Guibas, "Registration of Point Cloud Data from a Geometric Optimization Perspective, "In Proc. Symposium on Geometry Processing 2004, pp.2332, 2004

[7] V. Sequeira, J. Goncalves and M. Isabel Ribeiro, "3D Scene Modelling from Multiple Range Views, "In Proc. SPIE Conference Videometrics IV (part of Photonics East' 95), Vol.2598, pp.114-127, 1995.

[8] A. Johnson and M. Hebert, "Surface Registration by Matching Oriented Points, "In Proc. Int. Conf. on Recent Advances in 3-D Digital Imaging and Modeling, pp.121-128, May 1997.

[9] D. Akca, "Full Automatic Registration of Laser Scanner Point Clouds, "Optical 3-D Measurement Techniques VI, Vol. I, pp.330-337, Zurich, Switzerland, 2003.

[10] I. Stamos and M. Leordeanu, "Automated FeatureBased Range Registration of Urban Scenes of Large Scale, "IEEE International Conference of Computer Vision and Pattern Recognition 2003, WI, Vol. II, pp.555-561, June 16-22 2003.

[11] Y. Sun, J. Paik, A. Koschan and M. Abidi, "Surface Modeling Using Multi-View Range and Color Images, "Integrated Computer Aided Engineering, Special Issue on Multi-Sensor Image Processing Techniques and Systems Vol.10 No.1 pp.37-50, 2003.

[12] Kwang-Ho Bae and Derek D. Lichti, "Automated Registration of Unorganised Point Clouds From Terrestrial Laser Scanners, "ISPRS 2004, pp.222-227, Istanbul, Turkey, 2004.

[13] 金野哲士，今野晃市，藤本忠博，千葉則茂，”測定点群を用 いた建造物モデリングのための特徵線抽出法と特徵線マッ チンング法 , "芸術科学会論文誌, Vol.5, No.3, pp.80-91, 2006.

[14] H. Wang and D. Suter, "A model-based range image segmentation algorithm using a novel robust estimator, "In Proc. 3rd International Workshop on SCTV,
2003.

[15] G. Taylor and L. Kleeman, "Robust range data segmentation using geometric primitives for robotic applications, "In Proc. 9th IASTED International Conference on Signal and Image Processing (SIP2003), pp.467-472, Honolulu, 2003.

[16] J. Min and Kebin W. Bowyer, "Improved range image segmentation by analyzing surface fit patterns, "Computer Vision and Image Understanding, Vol.97, Issue 2, pp.242-258, 2005.

[17] Wani, M.A. and B.G. Batchelor, "Edge Region Based Segmentation of Range images, "IEEE Trans. Pattern Analysis and Machine Intelligence, Vol.16, Issue 3, pp.314-319, 1994.

[18] Y. Zhang, Y. Sun, H. Sari-Sarraf, M. Abidi, "Impact of Intensity Edge Map on Segmentation of Noisy Range Images, "In Proc. SPIE Conf. on ThreeDimensional Image Capture and Applications III, Vol.3958, pp.260-269, San Jose, CA, 2000.

[19] A. D. Sappa and M. Devy, "Fast Range Image Segmentation by an Edge Detection Strategy, "In Proc. 3rd International Conference on 3-D digital Imaging and Modeling (3DIM'2001), pp.292-299, Quebec, Canada, 2001.

[20] Jiang, X.Y. and H. Bunke, "Fast Segmentation of Range Images into Planar Regions by Scan Line Grouping, "Machine Vision and Applications, Vol.7, Issue 2, pp.115-122, 1994.

[21] Fitzgibbon, A.W., D.W. Eggert, and R.B. Fisher, "High-Level CAD Model Acquisition from Range Images, "Technical Report, Dept. of Artificial Intelligence, Univ. of Edinburgh., 1995.

[22] Y. Yu, A. Ferencz and J. Malik, "Extracting objects from range and radiance images, "IEEE Trans. Visualization and Computer Graphics, Vol.7, No.4, pp.351-364, 2001.

[23] M.A. Fischler and R.C. Bolles, "Random sample consensus: A paradigm for model fitting with application to image analysis and automated cartography, "Communications of the ACM, Vol.6, no.24, pp.381-395, 1981.

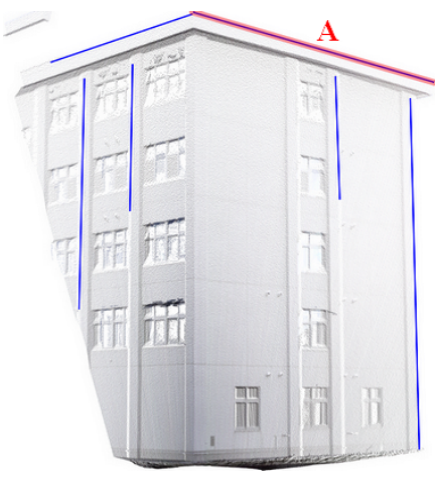

(a) 測定方向 1

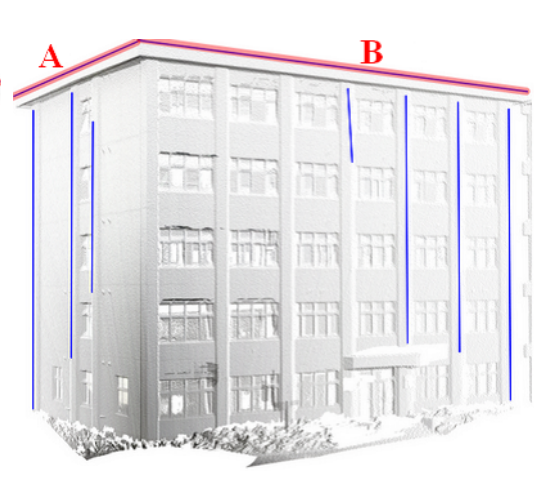

(b) 測定方向 2

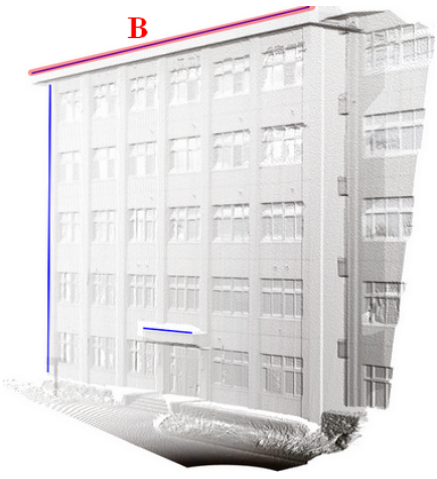

(c) 測定方向 3 


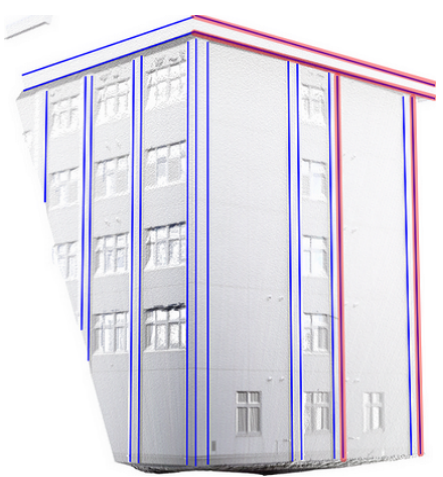

(a) 測定方向 1

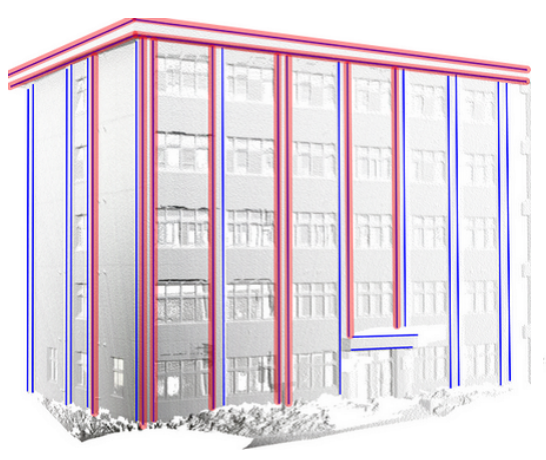

(b) 測定方向 2

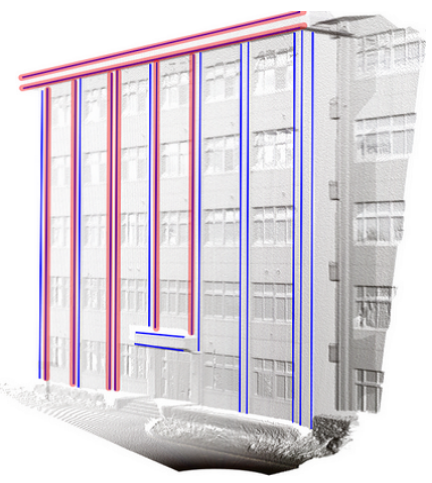

(c) 測定方向 3

図 13 本手法による特徵線抽出結果

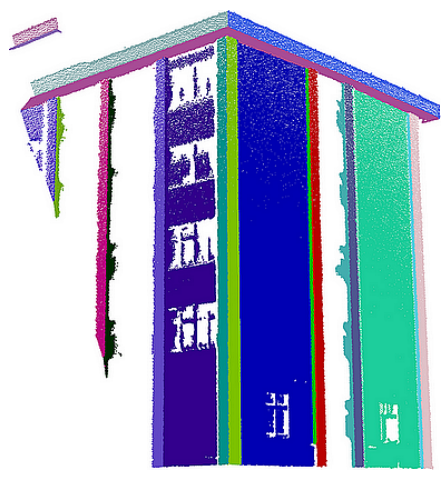

(a) 測定方向 1

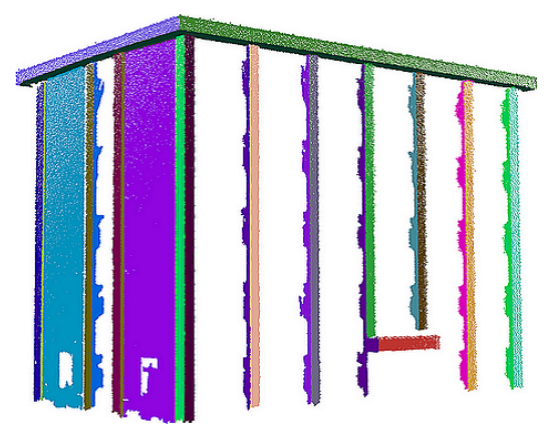

(b) 測定方向 2

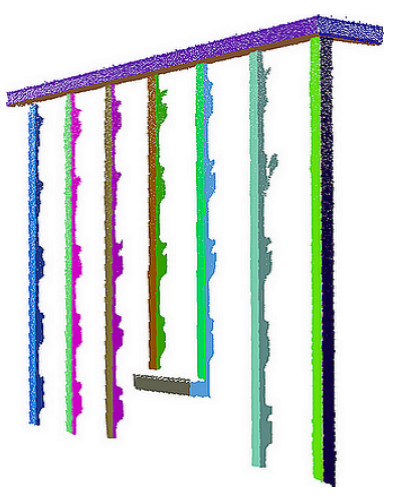

(c) 測定方向 3

図 14 稜線生成に使用した平面領域

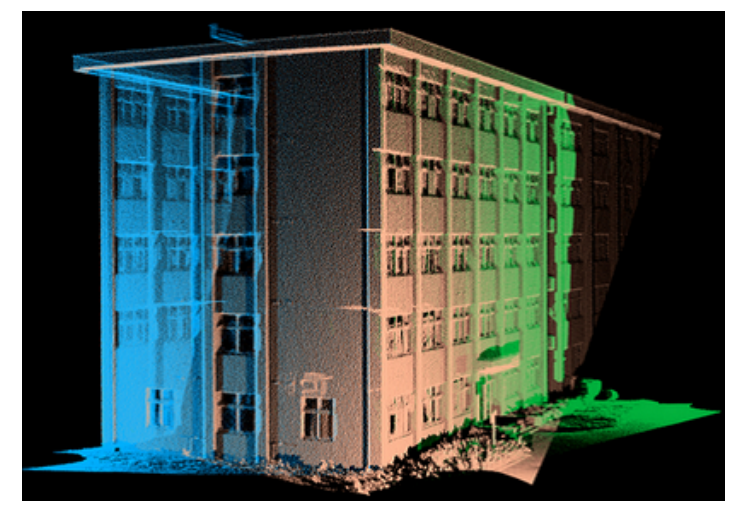

(a) 点群

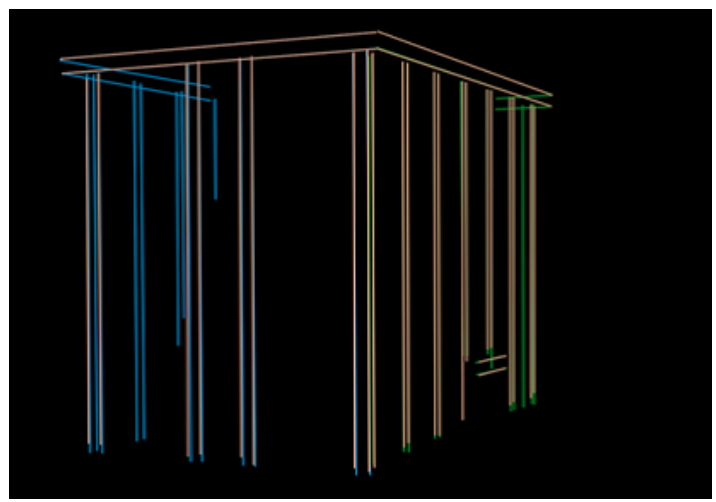

(b) 特徵線

図 15 位置合わせ処理後の点群と特徵線 